\title{
Strategies for high-altitude adaptation revealed from high-quality draft genome of non-violacein producing Janthinobacterium lividum ERGS5:01
}

\author{
Rakshak Kumar $^{* \dagger}$ (D), Vishal Acharya ${ }^{\dagger}$, Dharam Singh $^{*}$ and Sanjay Kumar
}

\begin{abstract}
A light pink coloured bacterial strain ERGS5:01 isolated from glacial stream water of Sikkim Himalaya was affiliated to Janthinobacterium lividum based on $16 \mathrm{~S}$ rRNA gene sequence identity and phylogenetic clustering. Whole genome sequencing was performed for the strain to confirm its taxonomy as it lacked the typical violet pigmentation of the genus and also to decipher its survival strategy at the aquatic ecosystem of high elevation. The PacBio RSII sequencing generated genome of 5,168,928 bp with 4575 protein-coding genes and 118 RNA genes. Whole genome-based multilocus sequence analysis clustering, in silico DDH similarity value of $95.1 \%$ and, the ANI value of $99.25 \%$ established the identity of the strain ERGS5:01 (MCC 2953) as a non-violacein producing J. lividum. The genome comparisons across genus Janthinobacterium revealed an open pan-genome with the scope of the addition of new orthologous cluster to complete the genomic inventory. The genomic insight provided the genetic basis of freezing and frequent freeze-thaw cycle tolerance and, for industrially important enzymes. Extended insight into the genome provided clues of crucial genes associated with adaptation in the harsh aquatic ecosystem of high altitude.
\end{abstract}

Keywords: Janthinobacterium lividum, Sikkim Himalaya, Comparative genomics, High-altitude adaptation

\section{Introduction}

The genus Janthinobacterium was derived from the genus Chromobacterium (mesophilic, fermentative bacteria producing purple and violet colonies) to separate nonfermentative and psychrophilic bacteria producing violet colonies [1]. Hence, the most common feature of this genus is psychrophilic bacteria producing violet pigment violacein [1]. However, there have also been reports on partly pigmented and non-pigmented bacteria within this genus $[1,2]$. In the present study, a light pink coloured bacterial strain ERGS5:01 isolated from glacial stream water sample in Sikkim Himalaya was affiliated to Janthinobacterium lividum by $16 \mathrm{~S}$ rRNA gene sequence identity and phylogeny. The lack of typical violet pigmentation intrigued us to establish its taxonomic identity using whole genome sequencing. MLSA using

\footnotetext{
* Correspondence: rakshak@ihbt.res.in; dharamsingh@ihbt.res.in

${ }^{\dagger}$ Equal contributors

Biotechnology Division, CSIR-Institute of Himalayan Bioresource Technology, Post BoxNo.06, Palampur, Himachal Pradesh 176 061, India
}

multiple concatenated housekeeping genes was applied to investigate the phylogenetic position of the strain within Janthinobacterium. This method has been widely used to resolve the taxonomic position of closely related prokaryotic species within a genus [3]. The availability of whole genome sequences of multiple strains further allowed in silico DDH and ANI to confirm the taxonomic position of the strain with higher certainty [4].

The genus Janthinobacterium has a wide occurrence ranging from soil, aquatic sites, marine habitats, high altitude environments with a unique ability to survive and colonise new environments $[5,6]$. With the revolution in the field of microbial genomics and analyses such as pan-genome, it becomes handy to compare many strains of a species or genus to obtain a complete inventory of genes [7]. We used the genome sequence of strain ERGS5:01 and other strains to study the genomic diversity within this genus. The bacterial strain was isolated from an aquatic ecosystem of a high altitude region (4718 masl) [8]. Organisms in such

(c) The Author(s). 2018 Open Access This article is distributed under the terms of the Creative Commons Attribution 4.0 International License (http://creativecommons.org/licenses/by/4.0/), which permits unrestricted use, distribution, and reproduction in any medium, provided you give appropriate credit to the original author(s) and the source, provide a link to the Creative Commons license, and indicate if changes were made. The Creative Commons Public Domain Dedication waiver (http://creativecommons.org/publicdomain/zero/1.0/) applies to the data made available in this article, unless otherwise stated. 
environment sustain temperature fluctuation and are exposed to strong ultraviolet-B radiation, with low nutrient availability. $[9,10]$. Bacterial cold associated adaptive traits to withstand such harsh conditions includes proteins required to maintain molecular central dogma and membrane fluidity at low temperature. [11]. Other associated proteins are those which response to osmotic, oxidative and cold stress [12]. The copy number of these proteins have often been reported to increase to accelerate the number of active sites to neutralise the lowered enzymatic rates at low temperatures by the cold-active organisms [13]. In the present study, we present an extended genomic insight of strain ERGS5:01 to explore their taxonomic position and to identify potentially important proteins for their survival in harsh environments of the high altitude aquatic ecosystem.

\section{Organism information}

\section{Classification and features}

The East Rathong glacier falls in the survey of India toposheet no. 78A/2 within the Khangchendzonga National Park area in the Sikkim Himalaya. It lies between 27 33' and $27^{\circ} 36^{\prime} \mathrm{N}$ latitude and $88^{\circ} 04$ and $88^{\circ} 08^{\prime} \mathrm{E}$ longitude in the West district of the state Sikkim in India [14]. During the isolation of psychrotrophs to explore for bioprospection, this aerobic chemoheterotrophic bacterial strain ERGS5:01 was isolated from a glacial stream located in the ablation zone of East Rathong glacier at an altitude of 4718 masl [8].The bacteria was isolated on ABM agar plates [peptone $(0.5 \%, w / v)$, yeast extract $(0.2 \%, \mathrm{w} / \mathrm{v})$ and agar $(2 \%, \mathrm{w} / \mathrm{v})]$ [15] by incubating at $10{ }^{\circ} \mathrm{C}$ for 15 days. ERGS5: 01 is a gram-negative, aerobic bacteria with optimum growth at $10^{\circ} \mathrm{C}$. The strain produced light pink colour colonies after a $72 \mathrm{~h}$ incubation at temperature $15{ }^{\circ} \mathrm{C}, 10{ }^{\circ} \mathrm{C}$, and $4{ }^{\circ} \mathrm{C}$. The colonies were found to be round, convex and entire. This bacteria could grow at the temperature range of $4-28{ }^{\circ} \mathrm{C}, \mathrm{NaCl}$ concentration range of $1 \%$ to $4 \%$, and $\mathrm{pH}$ range of 3-10 pH (Table 1). Scanning electron microscopy revealed the shape of the bacteria as short rods with an average length of 0.8 to $1.1 \mu \mathrm{m}$ (Fig. 1).

\section{Extended feature descriptions}

16S rRNA gene analysis Sequence identity search based on 16S rRNA gene sequence (1341 bp/ NCBI Accession No. KT766048) of strain ERGS5:01 with a database of type strains as available in NCBI [16] exhibits closest sequence identity of $99 \%$ with J. lividum PAMC 25724. Phylogenetic clustering constructed using Neighbor-Joining tree using Jukes-Cantor model of sequence evolution with 1000 bootstrap replications using Molecular Evolutionary Genetics Analysis version 7.0 [17] also clustered the strain ERGS5:01 with J. lividum PAMC 25724 (Fig. 2).
Table 1 Classification and general features of Janthinobacterium lividum ERGS5:01 [18]

\begin{tabular}{|c|c|c|c|}
\hline MIGS ID & Property & Term & $\begin{array}{l}\text { Evidence } \\
\text { code }^{\mathrm{a}}\end{array}$ \\
\hline & Classification & Domain Bacteria & TAS [65] \\
\hline & & Phylum Proteobacteria & TAS [66] \\
\hline & & Class Betaproteobacteria & TAS [67] \\
\hline & & Order Burkholderiales & TAS [68] \\
\hline & & Family Oxalobacteraceae & TAS [69] \\
\hline & & Genus Janthinobacterium & TAS [69] \\
\hline & & Species lividum & TAS [69] \\
\hline & & $\begin{array}{l}\text { strain: ERGS5:01 } \\
\text { (Accession MCC 2953) }\end{array}$ & IDA \\
\hline & Gram stain & Negative & IDA \\
\hline & Cell shape & Short rods & IDA \\
\hline & Motility & Motile & IDA \\
\hline & Sporulation & Nonsporulating & IDA \\
\hline & $\begin{array}{l}\text { Temperature } \\
\text { range }\end{array}$ & $4-28^{\circ} \mathrm{C}$ & IDA \\
\hline & $\begin{array}{l}\text { Optimum } \\
\text { temperature }\end{array}$ & $10^{\circ} \mathrm{C}$ & IDA \\
\hline & $\begin{array}{l}\text { pH range; } \\
\text { Optimum }\end{array}$ & $3-10 ; 7$ & IDA \\
\hline & $\begin{array}{l}\text { Carbon } \\
\text { source }\end{array}$ & $\begin{array}{l}\text { Xylose, Maltose, Fructose, } \\
\text { Dextrose, Raffinose, } \\
\text { Trehalose, o-nitrophenyl- } \beta \text { - } \\
\text { D-galactoside, Esculin }\end{array}$ & IDA \\
\hline MIGS-6 & Habitat & Water, Glacial stream & IDA \\
\hline MIGS-6.3 & Salinity & $1 \%$ to $4 \% \mathrm{NaCl}$ & IDA \\
\hline MIGS-22 & $\begin{array}{l}\text { Oxygen } \\
\text { requirement }\end{array}$ & Aerobic & IDA \\
\hline MIGS-15 & $\begin{array}{l}\text { Biotic } \\
\text { relationship }\end{array}$ & free-living & IDA \\
\hline MIGS-14 & Pathogenicity & NonPathogenic & NAS \\
\hline MIGS-4 & $\begin{array}{l}\text { Geographic } \\
\text { location }\end{array}$ & West Sikkim, India & IDA \\
\hline MIGS-5 & $\begin{array}{l}\text { Sample } \\
\text { collection }\end{array}$ & 02-May-2015 & IDA \\
\hline MIGS-4.1 & Latitude & $27^{\circ} 33^{\prime \prime} 15^{\prime \prime} N$ & TAS [6],IDA \\
\hline MIGS-4.2 & Longitude & $88^{\circ} 07^{\prime} 406^{\prime \prime} \mathrm{E}$ & TAS [6],IDA \\
\hline MIGS-4.4 & Altitude & 4718 & TAS [6], IDA \\
\hline
\end{tabular}

avidence codes - IDA Inferred from Direct Assay, TAS Traceable Author Statement (i.e., a direct report exists in the literature), NAS Non-traceable Author Statement (i.e., not directly observed for the living, isolated sample, but based on a generally accepted property for the species, or anecdotal evidence). These evidence codes are from the Gene Ontology project [70]

Biochemical profiling, extracellular enzyme assay, freezing and freeze-thaw tolerance The strain ERGS5: 01 was tested for various biochemical activities such as catalase, oxidase, triple sugar iron, citrate utilisation, urease, indole, MR-VP, motility and carbohydrate utilisation (KB009 HiCarbohydrate ${ }^{\mathrm{Tm}}$ kit, HiMedia).The strain was observed as gram-negative short rods, motile, non- 


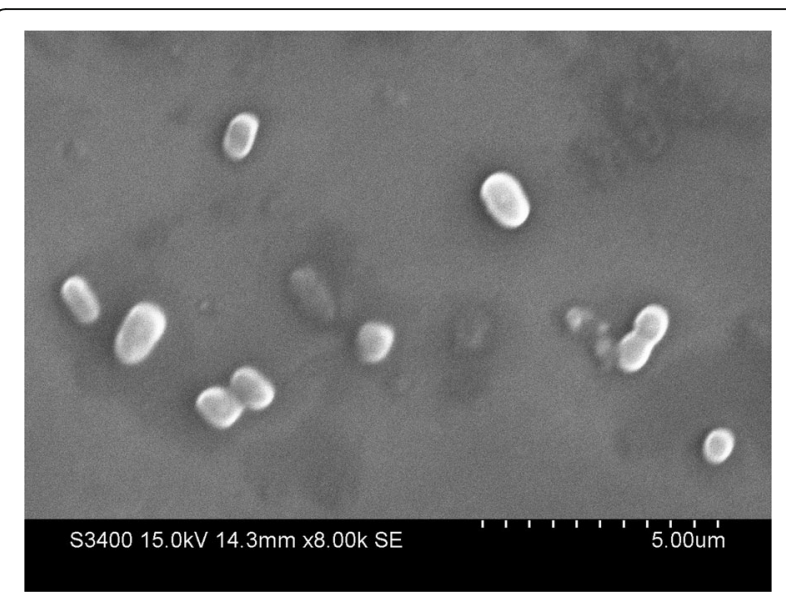

Fig. 1 Scanning electron micrograph of strain J. lividum ERGS5:01 grown at ABM agar plates for $48 \mathrm{~h}$ at $10^{\circ} \mathrm{C}$. for 15 days. Bar, $5 \mu \mathrm{m}$

fermentative, positive in oxidase, catalase and urease and negative in MR-VP test. Out of the 35 sugars tested, this strain could utilize xylose, maltose, fructose, dextrose, raffinose, trehalose, o-nitrophenyl- $\beta$-D-galactoside, esculin while it could not utilize lactose, galactose, melibiose, sucrose, L-arabinose, mannose, inulin, sodium gluconate, glycerol, dulcitol, inositol, sorbitol, mannitol, adonitol, arabitol, erythritol, $\alpha$-methyl-D- glucoside, ribose, rhamnose, cellobiose, melezitose, $\alpha$-methyl-D-mannoside, xylitol, D-arabinose, malonate and, sorbose. The extracellular enzymatic activities namely amylase, lipase, protease and cellulase for strain ERGS5:01 were analysed using standard plate assay at $10{ }^{\circ} \mathrm{C}$. The strain showed positive results for amylase, lipase, and protease activities. Survival percentage for freezing and frequent freeze-thaw cycle tolerance was tested by colony count method considering count on day 0 as $100 \%$ as described by Shivaji et al. [15]. For freeze tolerance, 27 tubes of $1 \mathrm{ml}$ culture were allowed to reach stationary phase using $\mathrm{ABM}$ broth, and 24 of them were placed at $-20{ }^{\circ} \mathrm{C}$. At each time point $(1,3,5,7,9,11,13,15$ days of freezing), three tubes were removed, thawed for $1 \mathrm{~h}$ at $10{ }^{\circ} \mathrm{C}$ and $100 \mu \mathrm{l}$ were serially diluted in $900 \mu \mathrm{l}$ of $0.9 \%$ saline. Three unfrozen tubes served as zero time point. The diluted culture was plated on ABM agar and incubated for $3-5$ days at $10{ }^{\circ} \mathrm{C}$. The mean from triplicate colony counts results were used for determining the survival percentage considering the cell count on day 0 as $100 \%$. For freeze-thaw cycle tolerance, a similar procedure as described for freezing tolerance was followed, but freezing and thawing were in continuous cycles $(1,3,5,7,9,11,13,15$ cycles $)$. Each cycle comprised of freezing at $-20{ }^{\circ} \mathrm{C}$ for $1 \mathrm{~h}$ followed by thawing at $10{ }^{\circ} \mathrm{C}$ for $1 \mathrm{~h}$. We used E. coli MTCC 43 as a negative control because the strain showed optimum growth at $37{ }^{\circ} \mathrm{C}$. The strain survived the freezing temperature of $-20{ }^{\circ} \mathrm{C}$ for $30 \mathrm{~h}$ as no ice crystal formation was observed in the culture broth. The percentage survivability of our strain was observed to be $76.60 \%$ for day 1 . Subsequently, the survivability decreased to $41.12 \%, 20.9 \%$ and $19.35 \%$ on day 3,5 and 7 respectively. Further, from the 9th day, we observed growth below 10\% growth. On the other hand strain, E. coli MTCC43 showed a steep decline of $40 \%$ within $24 \mathrm{~h}$ of incubation and declined steadily in successive cycles with zero survivability from day 9 (Fig. 3a). The strain showed higher resistance to the freeze-thaw cycle compared to freezing. The strain survived $100 \%$ at the first cycle which further reduced to $72.58 \%, 70.77 \%, 41.93 \%$, $40.3 \%$ and $14.5 \%$ at subsequent cycle $3,5,7,9$ and 11 , respectively. Growth was observed to be seized on the 13 and 15 cycles. However, the survival of strain E. coli MTCC43 declined steadily to $67.27 \%$ in cycle 1 which further declined to $47.27 \%, 41.12 \%, 29.09 \%$ and $7.3 \%$ at subsequent cycles 3,5,7 and 9 respectively. Growth was observed to be seized at the cycles 11, 13 and 15 (Fig. 3b).

\section{Genome sequencing information Genome project history}

The whole genome of the strain ERGS5:01 was sequenced owing to its lack of usual violet pigmentation, typical to the genus Janthinobacterium, and their ability to survive harsh aquatic ecosystem of the high altitude region. The work was carried out as a part of a project to understand the genetic basis of survival of psychrotrophs and its bioprospection from East Rathong Glacier in the Sikkim Himalaya. The sequencing was completed at CSIR-Institute of Himalayan Bioresource Technology, Palampur using PacBio RS II platform (Microsynth AG, Switzerland). The draft genome has been deposited in GenBank under the accession MAQB00000000 while the version described in this paper is MAQB02000000. The project summary with minimum information about a genome sequence [18] is shown in Table 2.

\section{Growth conditions and genomic DNA preparation}

The strain ERGS5:01 was regularly grown at $10^{\circ} \mathrm{C}$ in $\mathrm{ABM}$ agar. Genomic DNA from the strains was extracted using GenElute $^{\mathrm{mx}}$ Bacterial Genomic DNA Kit (Sigma-Aldrich, US).The obtained genomic DNA was evaluated for its quality and quantity using $1 \%$ agarose gel electrophoresis and Qubit 2.0 Fluorometer (Invitrogen, USA).

\section{Genome sequencing and assembly}

Shearing of genomic DNA $(10 \mu \mathrm{g})$ was done using gTUBE $^{\mathrm{Tm}}$ (Covaris, US) and DNA library was prepared using $10 \mathrm{~kb}$ insert size with PacBio SMRTbell library preparation kit v1.0 [6]. Quantification of the prepared library was done using Qubit 2.0 Fluorometer (Invitrogen, USA). Sequencing was performed using PacBio RSII system (Pacific Biosciences, US) as described previously 


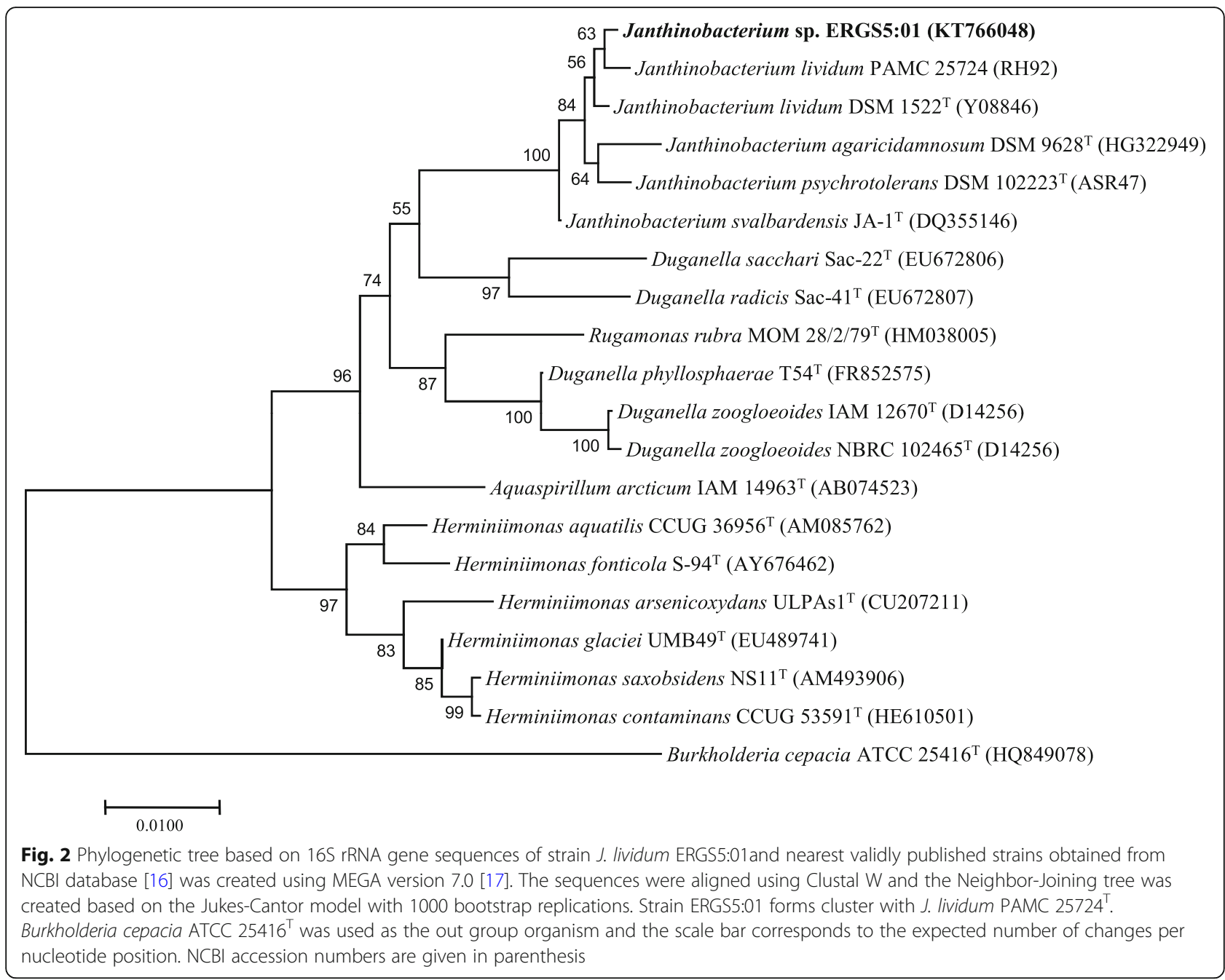

$[19,20]$. Assembly of the generated subreads was performed de novo using RS hierarchical genome assembly process protocol version 3.0 (HGAP.3) in SMRT Analysis version 2.3.0 (Pacific Biosciences, US).

\section{Genome annotation}

Annotation of the high-quality draft genome was performed using the JGI Prokaryotic Automatic Annotation Pipeline [21] with the additional analysis and the manual review being done within the IMG platform [22, 23]. The functions of the predicted protein-coding genes and genes with Pfam domains were assigned using the Interpro platform [24]. Genes assigned to COGs were assigned by searching against COG database (from the NCBI conserved domain database [25]) using rpsblast with significant E-value of 0.0001.BLASTclust with thresholds of 70\% covered length and 30\% sequence identity was used to obtain the number of genes in internal clusters [26]. Signal peptides and transmembrane helices were predicted using SignalP [27] and TMHMM [28] respectively. CRISPR database was used to identify CRISPR repeats in the genome [29].

\section{Genome properties}

The strain ERGS5:01 was assembled into 16 contigs containing the genome of total $5,168,928$ bp with a $\mathrm{G}+\mathrm{C}$ content of $60.48 \%$ (N50 contig length of 3,372,370 bp with average reference coverage of $38.09 \mathrm{X}$ ). A total of 4693 genes were predicted out of which 4575 were protein-coding genes, 118 were RNA genes ( 25 rRNAs, 90 tRNAs, and three non-coding RNAs) and 600 pseudo genes (Table 3). The circular chromosomal map for the draft genome is presented in Fig. 4 using ClicO FS, an online service based on Circos [30]. From COG database, 2559 genes were assigned to biological functions and 3160 genes $(67.33 \%)$ were reported to be assigned to protein families. Table 3 summarises the genome properties and statistics, and Table 4 presents the distribution of genes into COG functional categories. 

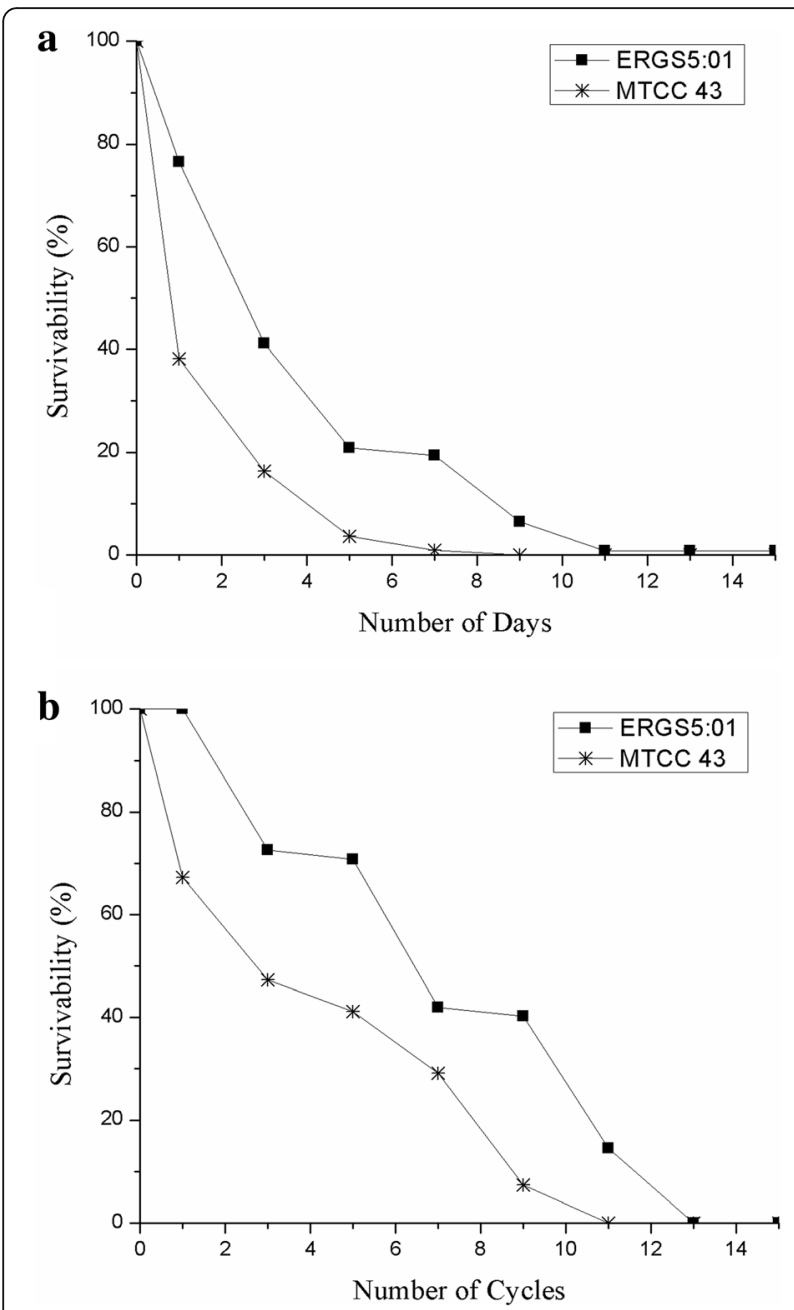

Fig. 3 Survival of strain J. lividum ERGS5:01 to freezing (a) and freeze-thaw cycle (b)using colony count method considering the count of unfrozen sample as $100 \%$. a Freeze tolerance up to 15 days at $-20^{\circ} \mathrm{C}$. b Freeze-thaw cycle tolerance up to 15 cycles with cycle consisting of $1 \mathrm{~h}$ of freezing at $-20^{\circ} \mathrm{C}$ and thawing for $1 \mathrm{~h}$ at $10^{\circ} \mathrm{C}$. Mean of triplicate colony count were used to calculate survival percentage and strain E. coli MTCC43 was used as negative control

\section{Insights from the genome sequence and comparative genomics}

The strain ERGS5:01 appeared sister to J.lividum PAMC 25724 based on its $16 \mathrm{~S}$ rRNA gene sequence identity and phylogeny (Fig. 2). However, the 16S rRNA gene sequence identity between other species of Janthinobacterium also showed an identity above the threshold value (>98.7\%) (Table 5) as recommended for species identity by MeierKolthoff et al. [31]. The insufficiency of 16S rRNA genes in resolving species for many genera [3] led us further explore the phylogenetic position of the strain ERGS5:01 using six housekeeping genes namely, rpoB, aroE, gmk, $\operatorname{Rec} A, \operatorname{gyr} B$ and tpi. These genes were retrieved from whole genome sequence available from strain ERGS5:01 and other 20 Janthinobacterim strains. Multiple alignments
Table 2 Project information

\begin{tabular}{|c|c|c|}
\hline MIGS ID & Property & Term \\
\hline MIGS 31 & Finishing quality & Level 2: High Quality Draft \\
\hline MIGS-28 & Libraries used & $\begin{array}{l}\text { SMRTbell Template Prep kit v1.0 } \\
(20 \mathrm{~kb})\end{array}$ \\
\hline MIGS 29 & $\begin{array}{l}\text { Sequencing } \\
\text { platforms }\end{array}$ & PacBio \\
\hline MIGS 31.2 & Fold coverage & $38.09 x$ \\
\hline MIGS 30 & Assemblers & $\begin{array}{l}\text { Hierarchical Genome Assembly } \\
\text { Process v. } 3\end{array}$ \\
\hline \multirow[t]{6}{*}{ MIGS 32} & Gene calling method & Prodigal \\
\hline & Locus Tag & BA896 \\
\hline & Genbank ID & MAQB00000000 \\
\hline & $\begin{array}{l}\text { GenBank Date of } \\
\text { Release }\end{array}$ & October 16, 2016 \\
\hline & GOLD ID & Gp0177310 \\
\hline & BIOPROJECT & PRJNA327173 \\
\hline \multirow[t]{2}{*}{ MIGS 13} & $\begin{array}{l}\text { Source Material } \\
\text { Identifier }\end{array}$ & MCC 2953 \\
\hline & Project relevance & High altitude environment \\
\hline
\end{tabular}

were performed using MAFFT, statistics for each locus was summarised using MEGA 7, and phylogenetic tree of concatenated six housekeeping genes was constructed using maximum likelihood method based on the JTT matrixbased model in MEGA 7 [32]. Neighbour-joining tree constructed with six concatenated housekeeping genes for MLSA analysis agreed with the data generated by the maximum likelihood method described above (Additional file 1: Figure S1).The MLSA clustering revealed monophyly of strain ERGS5:01 and J. lividum PAMC 25724 (Cluster II)

Table 3 Genome statistics

\begin{tabular}{lll}
\hline Attribute & Value & $\%$ of Total \\
\hline Genome size (bp) & $5,168,928$ & $100.00 \%$ \\
DNA coding (bp) & $4,513,533$ & $87.32 \%$ \\
DNA G + C (bp) & $3,126,125$ & $60.48 \%$ \\
DNA scaffolds & 16 & $100.00 \%$ \\
Total genes & 4693 & $100.00 \%$ \\
Protein coding genes & 4575 & $97.49 \%$ \\
RNA genes & 118 & $2.51 \%$ \\
Pseudo genes & \\
Genes in internal clusters & 600 & $12.78 \%$ \\
Genes with function prediction & 805 & $17.15 \%$ \\
Genes assigned to CoGs & 2988 & $63.67 \%$ \\
Genes with Pfam domains & 2559 & $54.53 \%$ \\
Genes with signal peptides & 3160 & $67.33 \%$ \\
Genes with transmembrane helices & 435 & $9.27 \%$ \\
CRISPR repeats & 908 & $19.35 \%$ \\
\hline
\end{tabular}

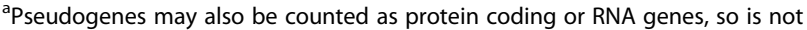
additive under total gene count 


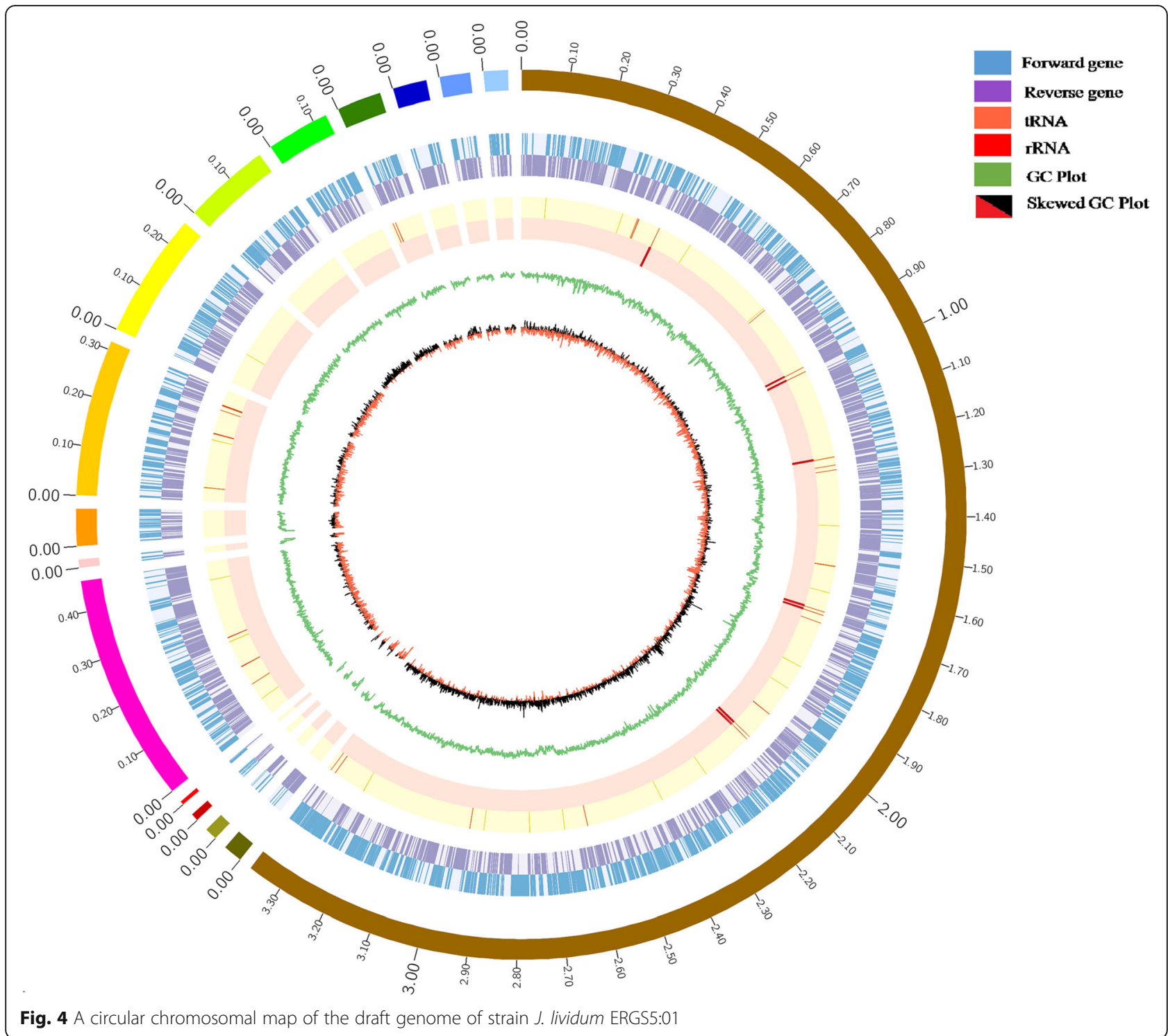

coherent to the 16S rRNA phylogeny (Fig. 5). This group formed a sister clade with other J. lividum strains with strong bootstrap support of 98\% (Cluster I) (Fig. 5). Such distinct separation among J. lividum strains prompted us to carry out an exhaustive automatic BLAST as well as manual searches to elucidate the presence of vioABCDE operon genes among genomes available from J. lividum strains. Interestingly, the distinct violacein pigment (from which the genus Janthinobacterium derives its name) producing genes were absent in both the strains of cluster II and all the strains among cluster I contained vioABCDE operons (Fig. 5). Hence, the separation of two clusters among J. lividum strains was based on possession of vioABCDE operons. We then performed whole genome sequence-based in silico DDH using the online genome-to-genome calculator with the GGDC 2.0 BLAST+ model [33] and ANI using nucleotide fasta sequences of each genome compared to the genome of strain ERGS5:01 as a reference with the Perl script [34]. The observed DDH value was $95.15 \%$ and, ANI value was $99.25 \%$ between strain ERGS5:01 and PAMC 25724 (Table 5 and Additional file 2: Table S1). Both the values qualify above the cut-off value for species boundary $[33,34]$, and hence the results were consistent with the MLSA clustering of strain ERGS5:01 with PAMC 25724. In a recent study, strain PAMC 25724 has been reported as the strain of the species J. lividum [35] and is a validly published species with the availability of culture at Polar and Alpine Microbial Collection with accession number 25724. In another study, strains HH100, HH102, HH103, HH104, HH106, HH107, and 5059B had shown to be clustered together in proximity to J. lividum DSM 1522 [6]. Based on DDH and ANI values and MLST clustering, the strain ERGS5:01 could be affiliated to a non-violaecin producing strain of J. lividum. We also propose that strain ERGS5:01 
Table 4 Number of genes associated with general COG functional categories

\begin{tabular}{|c|c|c|c|}
\hline Code & Value & \%age & Description \\
\hline J & 187 & $6.51 \%$ & Translation, ribosomal structure and biogenesis \\
\hline A & 1 & $0.03 \%$ & RNA processing and modification \\
\hline K & 207 & $7.21 \%$ & Transcription \\
\hline L & 91 & $3.17 \%$ & Replication, recombination and repair \\
\hline B & 2 & $0.07 \%$ & Chromatin structure and dynamics \\
\hline $\mathrm{D}$ & 27 & $0.94 \%$ & Cell cycle control, Cell division, chromosome partitioning \\
\hline V & 66 & $2.30 \%$ & Defense mechanisms \\
\hline T & 240 & $8.35 \%$ & Signal transduction mechanisms \\
\hline M & 198 & $6.89 \%$ & Cell wall/membrane biogenesis \\
\hline $\mathrm{N}$ & 140 & $4.87 \%$ & Cell motility \\
\hline$U$ & 76 & $2.65 \%$ & Intracellular trafficking and secretion \\
\hline $\mathrm{O}$ & 131 & $4.56 \%$ & Posttranslational modification, protein turnover, chaperones \\
\hline C & 144 & $5.01 \%$ & Energy production and conversion \\
\hline G & 130 & $4.52 \%$ & Carbohydrate transport and metabolism \\
\hline $\mathrm{E}$ & 221 & $7.69 \%$ & Amino acid transport and metabolism \\
\hline F & 71 & $2.47 \%$ & Nucleotide transport and metabolism \\
\hline $\mathrm{H}$ & 145 & $5.05 \%$ & Coenzyme transport and metabolism \\
\hline I & 121 & $4.21 \%$ & Lipid transport and metabolism \\
\hline P & 147 & $5.12 \%$ & Inorganic ion transport and metabolism \\
\hline Q & 51 & $1.78 \%$ & Secondary metabolites biosynthesis, transport and catabolism \\
\hline $\mathrm{R}$ & 216 & $7.52 \%$ & General function prediction only \\
\hline S & 153 & $5.33 \%$ & Function unknown \\
\hline- & 2134 & $45.47 \%$ & Not in COGs \\
\hline
\end{tabular}

The total is based on the total number of protein coding genes in the genome

and PAMC 25724 has the scope of reassessment of their taxonomic position under J. lividum that will require further comparative polyphasic taxonomic studies. The strain ERGS5:01 is deposited in the MCC at National Centre for Cell Science, Pune, India with accession number MCC 2953 (Additional file 3: Figure S2).

The psychrotrophic strain ERGS5:01 isolated from the glacial stream was found to tolerate freezing as well as frequent freeze-thaw cycles. The phenomenon is corroborated by the presence of numerous genes encoding for proteins responsible for cold adaptation. Genes encoding for coldshock proteins; multi-enzyme complex (UvrD helicase, UvrABC helicase, UvrB/UvrC); DNA repair proteins (RecN,
RecO, RadA, MutS, deoxyribose dipyrimidine photolyase); and cluster of chaperone proteins (ClpB, DnaK, Dna), Hsp31, HtpG, SurA, HscA, EcpD and FliS) were observed in the genome of strain ERGS5:01. An elaborate discussion on such genes associated with cold adaptation from the strain is presented under extended insight section of this paper. On plate assay, the strain was observed to produce cold active extracellular enzymes namely amylase, lipase, and protease. Hence, the genomic data were checked for the presence of potential industrially important enzymes using data mining. Genomic data supported the plate assay results as we obtained one copy of alpha-amylase and serine protease along with three copies of lipase-encoding

Table 5 Sequence identity of Janthinobacterium lividum ERGS5:01 with validly described species of genus Janthinobacterium; 16S rRNA gene sequence identity and whole genome sequence-based in silico comparison for DDH and ANI

\begin{tabular}{llll}
\hline Strain Name & 16S rRNA gene identity ${ }^{a}$ & DDH (Model-based Confidence Interval) (\%) & ANI (\%) \\
\hline Janthinobacterium lividum PAMC25724 & $99 \%$ & $95.10(93.5-96.3)$ & 99.25 \\
Janthinobacterium lividum DSM 1522 & $99 \%$ & $38.30(35.9-40.9)$ & 89.53 \\
Janthinobacterium psychotolerans S3-2 & $99 \%$ & $26.80(24.4-29.3$ & 82.13 \\
Janthinobacterium agaricidamnosum DSM 9628 & $99 \%$ & $23.00(20.7-25.5)$ & 78.86 \\
\hline
\end{tabular}

Values for 16S rRNA identity are based on NCBI BLAST alignment of the ERGS5:01 16S rRNA gene against genomes in IMG 


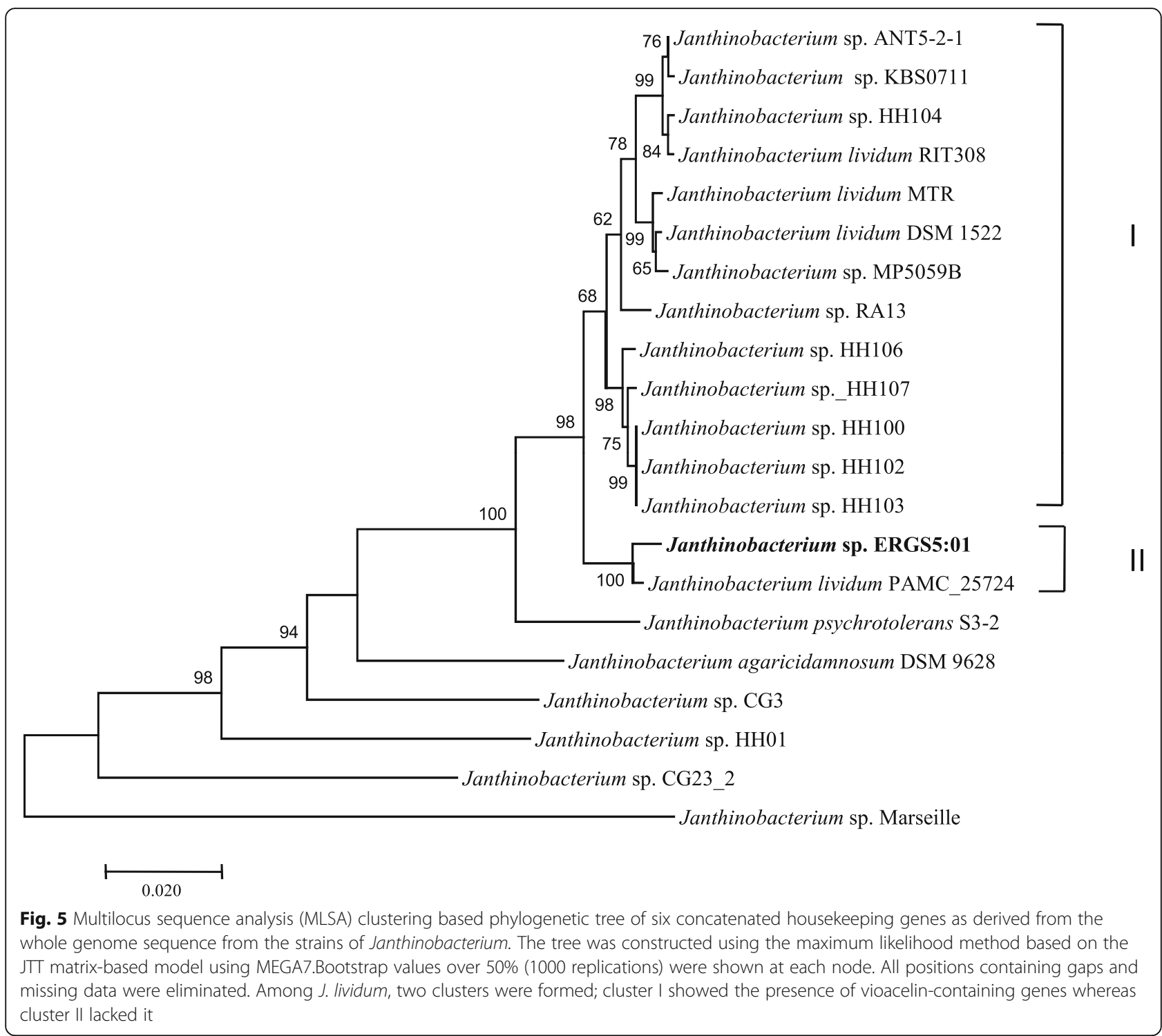

genes (Additional file 4: Table S2). The genomic data revealed multiple copies of some other noted industrially important enzymes like phospholipase, glycosyl transferase, alcohol dehydrogenase, catalase, alkaline phosphatase and chitinase (Additional file 4: Table S2).

Comparative genomic study was performed to reveal the genomic diversity across the genus Janthinobacterium. Genome data included J. agaricidamnosum DSM9628 (HG322949, [36]); J. psychotolerans S3-2 (LOCQ00000000, [35]) and J. lividum with multiple strains of Marseille (CP000269; [37]); Ant5-2 (LNCE00 000000, [38]); PAMC 25724 (AHHB00000000, [2]; CG3 (APFF00000000, [39]); HH01 (NZ_AMWD00000000, [40]); RIT308 (JFYR00000000, [41]); MTR (JRRH0000 0000, [42]);RA13 (JQNP01000001, [43]); KBS0711 (LB CO00000000, [44]); CG23_2 (CYSS00000000, [45]); DSM1522 (LRHW00000000), MP5059B (LRHX0000
0000), HH100 (LRHY00000000), HH102 (LRHZ0000 0000), HH103 (LRIA00000000), HH104 (LRIB00000000) , HH106 (LRIC00000000), and HH107 (LRID00000000) [4]. Few other genome sequence were retrieved from Gold database or IMG [22, 23]: J. lividum strain NFR18 (FPKH00000000); Janthinobacterium sp. strains 551a (FMXD01000000), OK676 (FNHA01000000), 344 (FO KL01000001.1), TND4EL3 (FTMV00000000) and YR213 (FNDA01000000).

The genome-wide amino-acid analysis of all 27 psychrotolerant Janthinobacterium strains revealed broad similarities in the usage profiles of Ala, Leu, Gly, and Val as the most frequently used amino acids. An ultra-fast computational pipeline Bacterial Pan Genome Analysis Tool [46] was used to assess all 27 genomes for comprehensive pangenome studies based on power law model. The pangenome curve perfectly fits a power law function with an 
exponent of 0.447968 indicating that the pan-genome of the genus Janthinobacterium is open (Additional file 5: Figure S3). Greater than zero exponents and, open pangenome correspond to the incomplete gene inventory with the scope of the additions of new orthologous clusters $[7,47]$. The orthologous gene cluster for the pangenome (complete gene family) was observed to be 21,349 out of which $1066(\sim 5 \%)$ were core genome. Core genomes represent the list of gene families shared by all 27 Janthinobacterium genomes. All the strains reported under the genus were psychrotolerant. Interestingly, we obtained various categories of genes associated with cold adaptation within the list of core genomes (namely, twocomponent histidine kinase, cold-shock proteins, coldactive chaperone, DNA repair, carbon storage/starvation, membrane/cell wall alteration and oxidative stress) (Additional file 6: Table S3). Among the core genomes of 27 strains, $\sim 95 \%$ of the genes could be assigned to COG categories (Additional file 7: Table S4). The highest percentage of the genes (17.5\%) in these COG categories were associated with signal transduction mechanism (Additional file 7: Table S4). Likewise, a recent report on Pseudoalteromonas haloplanktis TAC125 has discussed the role of major stimulus signalling transduction cascades-TCS histidine kinase on the bacterial adaptation to cold and deep water [48]. Total numbers of accessory genes observed were 20,283 which include the speciesspecific unique genes ranging from 0 to 2860 genes (Additional file 5: Figure S3). The open pan-genome with the discrepancy in the number of unique genes among strains strongly supports the high diversity in the genomic cluster of the genus Janthinobacterium. Importantly, strain CG23_2 which showed a maximum number of unique genes also has the largest genome in the genus Janthinobacterium [45]. All reported strains are psychrotolerant and have diverse habitat range as supported by the diversity in genomic structure revealed by the pangenome analysis.

\section{Extended genomic insights into adaptation to the high altitude aquatic environment}

Exhaustive data mining across the genome of strain ERGS5:01 was carried out to identify potential genes responsible for its assistance in the survival of aquatic high altitude environment. Multiple copies of genes for cold adaptation and other stress response proteins were observed as discussed below.

Two-component systems (TCS) histidine kinase and, signal transduction pathways TCS are widespread in bacteria, and used for monitoring and adapting to changes in their extra- or the intracellular environment. Various chemical and physical stimuli including $\mathrm{pH}$, temperature, oxidative stress induce differential expression of TCSs in bacteria [49]. Furthermore, this two-component histidinekinase system has been reported for their role in the bacterial survival at cold $[50,51]$. The genome of strain ERGS5:01 contained 58 copy numbers of such TCS. The report on blockage of cold-sensitive secretion pathway in E. coli has revealed the critical role of signal peptide/ secretion route for growth at low temperature with the aquatic environment [50]. Flagellin-specific chaperone (FliS) which binds to flagellin and facilitates bacterial transport was also observed in strain ERGS5:01. This observation further supports the presence of signal transduction and secretory pathways essential for survival at cold-temperature aquatic conditions.

Pigmentation Pigmentation of bacteria is reported to play an important role in cold and radiation adaptations [7].The strain ERGS5:01 lacked the usual violet pigment of the genus, and likewise there was no observation of violacein -producing gene (vioA, vioB, vioC, vioD, and $v i o E$ ) in the genome. However, it produced the light pink pigment that intrigued us to explore the genome for genes involved in carotenoid/ terpenoids biosynthesis pathway. Two copies of phytoene synthase genes and, one copy each of phytoene desaturase, phytoene dehydrogenase, lycopene beta-cyclase, octaprenyl diphosphate synthase, and dimethyl alanine transferase were observed. The presence of carotenoid/terpenoids biosynthesis pathway genes may assist this strain in providing tolerance to UV-B radiations, maintaining homeostasis during temperature fluctuations and adaptability in harsh condition of glacial ecosystems [9]. Multiple copies of genes like UvrD helicase (5), UvrABC helicase (1) and, UvrB/UvrC (1) were also observed which may assist against UV damage.

Oxidative stress response High exposure to UV radiations causes damage to bacteria surviving in extremely high altitude conditions by generating free radicals [52]. Increase in oxidative stress in Pseudomonas fluorescens MTCC 667 grown at low temperature was reported by the enhanced level of enzyme (namely, superoxide dismutase and catalase) activities and free radicals. [53]. Elevated activity of another antioxidant enzyme thioredoxin reductase in Listeria monocytogenes growing at $10{ }^{\circ} \mathrm{C}$ as compared to a reference culture grown at $37^{\circ} \mathrm{C}$ was also reported [54]. We observed numerous copies of putative oxidases genes in strain ERGS5:01 that leads to the production of large quantities of intrinsic $\mathrm{H}_{2} \mathrm{O}_{2}$ and other reactive oxygen species. The genome includes multiple copies of the thioredoxin (10), peroxiredoxin (5), alkyl hydroperoxide reductase (3), organic hydroperoxide reductase (2) and, a copy each of thioredoxin reductase, superoxide dismutase, catalase-peroxidase genes. 
DNA repair and cold-shock chaperones It has been well-reviewed and demonstrated that CSPs are strongly induced in bacteria in response to a rapid decrease in growth temperature [55-57]. CSPs are involved in RNA metabolism which prevents secondary structure formation and facilitates degradation of structured RNA, hence functioning as RNA chaperones. Two copies of genes inducing CSPs have been observed in the strain ERGS5:01 which potentially assist in the tuning of RNA metabolism in the cold adaptation. Increased expression of the $H t p G$ and GroEL gene have been observed in response to low temperatures in cyanobacterial strains, Synechococcus sp. PCC 7942 [58]. Similarly, strain ERGS5:01 also possess a single copy of $H t p G$, GroEL, and GroES genes which may involve in the acclimation to low temperatures.

Horizontal gene transfer (HGT) supporting adaptation to cold Numerous bacteria, unlike eukaryotes, have acquired a significant portion of DNA from distantly related organisms [59]. Such acquisitions have been reported to be prevalent in the prokaryotic genome with a low frequency of recombination and have greatly increased the genomic diversity, enabling bacteria to adapt and colonise in extreme and hostile conditions [60]. This phenomenon prompted us to investigate the occurrence of any such horizontally acquired genes in strain ERGS5:01 that may confer help in its adaptation to extreme conditions. Entire genes of strain ERGS5:01 were queried against the locally constructed database of other 19 Janthinobacterium genomes using BLAST with significant E-value of 1e-15. These blast results provided the list of 12 genes with no match against any available Janthinobacterium genomes indicating possibilities of HGT (Table 6). The $\mathrm{G}+\mathrm{C}$ compositions of these genes were also indicative of $\mathrm{HGT}$ as it varied from the usual $60 \% \mathrm{G}+\mathrm{C}$ of genus Janthinobacterium (Table 6) $[60,61]$. The HGT-acquired genes include two copies of glycosyl transferase family that participates in peptidoglycan biosynthesis involved in providing the protective shell around bacterial cell membranes and in cell elongation and cell division [62]. This enzyme has been reported to have increased expression in Shewanella oneidensis at low temperature [63] and might be considered as one of the crucial genes in the strain ERGS5:01for cold adaptation. Another important gene encoding for tellurium resistance protein namely $\mathrm{Ter} C$, a general stress response protein was also observed. In spite of the fact that some other Janthinobacterium genomes also possess genes encoding for TerC, yet the gene observed in strain ERGS5:01 suggested different amino-acid composition that was more closely related to Variovorax paradoxus with a sequence similarity of $84 \%$. Further studies are necessary to ascertain their specific role(s) for cold adaptation in strain ERGS5:01.

\section{Conclusion}

Sikkim Himalaya possesses untapped microbial resources with the tremendous scope of bioprospection [64]. Strain ERGS5:01 is one such light pink pigmented bacteria identified as J. lividum. The taxonomic identity of the strain remained uncertain as it lacked the usual violet pigmentation typical of the genus Janthinobacterium. Whole genome sequencing of the strain was performed owing to the discordance between unusual pigmentation and taxonomy and, survival at the harsh aquatic ecosystem. A high-quality draft genome of $5.1 \mathrm{Mb}$ was generated and deposited at GenBank under accession No. MAQB00000000. MLSA clustering allowed better phylogenetic resolution while

Table 6 Putative horizontally acquired genes of strain ERGS5:01; their closest match, gene length and G + C\% composition

\begin{tabular}{|c|c|c|c|c|}
\hline SI No. & Name of gene (GenBank No.) & Closest match in NCBI GenBank/percentage similarity (Phylum) & DNA (bp) & $\mathrm{G}+\mathrm{C}(\%)$ \\
\hline 1 & Transcriptional regulator (OFJ47798) & $\begin{array}{l}\text { Lysobacter/74\% } \\
\text { (Gammaproteobacteria) }\end{array}$ & 252 & 50.39 \\
\hline 2 & Glycosyltransferase family 1 (OFJ49554) & Polaromonas napthalenivorans/79\% (Betaproteobacteria) & 1155 & 56.88 \\
\hline 3 & Integrase (OFJ49513) & Burkholderia ubonensis/73\% (Betaproteobacteria) & 1050 & 50.19 \\
\hline 4 & Single-stranded DNA-binding protein (OFJ48621) & Burkholderia thailandensis/ 84\% (Betaproteobacteria) & 339 & 53.39 \\
\hline 5 & Terminase (OFJ46446) & Brachymonas chironomi/75\% (Betaproteobacteria) & 519 & 58.38 \\
\hline 6 & Sulphate transporter (OFJ46406) & Pseudomonas fluorescens/81\% (Gammaproteobacteria) & 624 & 59.29 \\
\hline 7 & Phage tail tape measure protein (OFJ46394) & Acinetobacter sp. NIPH 2168 /56\% (Gammaproteobacteria) & 1953 & 58.26 \\
\hline 8 & DNA-binding protein (OFJ50138) & Acidovorax avenae/ 71\% (Betaproteobacteria) & 1131 & 47.3 \\
\hline 9 & Tellurium resistance protein TerC (OFJ50276) & Variovorax paradoxus/ 84\% (Betaproteobacteria) & 2064 & 52.4 \\
\hline 10 & $\begin{array}{l}\text { Glycosyltransferase family } 2 \\
\text { (OFJ50221) }\end{array}$ & Pseudoduganella violaceinigra/81\% (Betaproteobacteria) & 933 & 49.9 \\
\hline 11 & $\begin{array}{l}\text { Flagellar motor protein MotB } \\
\text { (OFJ49983) }\end{array}$ & Variovorax paradoxus/86\% (Betaproteobacteria) & 717 & 49.79 \\
\hline 12 & Acetyltransferase (OFJ50217) & Xanthomonas axonopodis/ 72\% (Gammaproteobacteria) & 678 & 46.01 \\
\hline
\end{tabular}


genome based GGDH and ANI supported the clustering and confirmed the identity of strain as a non-violecin producing J. lividum. Further, strain ERGS5:01 was studied for its biochemical and physiological features for adaptational strategies such as freeze and freeze-thaw tolerance. The comparative pan-genome analysis revealed an open-pan genome with the scope of the addition of new orthologous cluster to complete the inventory of genes of Janthinobacterium and, the discrepancy in the number of unique genes among strains strongly supported the high diversity in the genomic cluster of this genus. The genomic insight of strain ERGS5:01 provided a genetic basis for its tolerance to freezing and frequent freeze-thaw cycles and the presence of industrially important enzymes. Extended genomic insights further provided a glimpse on crucial genes likely to be associated with the strategies to adapt harsh environment of high elevation.

\section{Additional files}

Additional file 1: Figure S1. Multilocus sequence analysis (MLSA) clustering based phylogenetic tree of six concatenated housekeeping genes as derived from the whole genome sequence from the strains of Janthinobacterium. The tree was constructed using the neighbor-joining method based on the JTT matrix-based model using MEGA7 Bootstrap values over 50\% (1000 replications) were shown at each node. All positions containing gaps and missing data were eliminated. The clustering patterns are in agreement with the data generated by the maximum likelihood method. (PDF $238 \mathrm{~kb}$ )

Additional file 2: Table S1. Whole genome sequence-based in silico comparison of strain ERGS5:01 and other related Janthinobacterium strains in database for DDH and ANI. (DOCX $17 \mathrm{~kb}$ )

Additional file 3: Figure S2. Certificate of deposition of strainERGS5:01 at Microbial Culture Collection (MCC) at National Centre for Cell Science, Pune, India. (PDF $377 \mathrm{~kb}$ )

Additional file 4: Table S2. Genes predicted to encode industrially important enzymes in the genome of J. lividum ERGS5:01. (DOCX $14 \mathrm{~kb}$ )

Additional file 5: Figure S3. Pan genome analysis of genus Janthinobacterium. The pan-genome profile plot displaying the total and the core gene families for each genome with a curve fit exponent of 0.43. [Number of unique genes observed for strains are displayed in brackets; 1. J. lividum ERGS5:01 (236); 2. J. sp. 551a (0); 3. J. agaricidamnosum DSM 9628 (1412); 4J. sp. CG23_2 (2860); 5. J. sp. CG3(1038); 6. J. sp. HH01 (1764) 7J. sp. KBS0711 (66) 8. J. lividum H-24 (217); 9. J. lividum NFR18 (86); 10. J. sp. Marseille (1625); 11. J. lividumMTR (197) 12.J. sp. OK676 (171); 13J. lividum PAMC25724 (152); 14. J. psychotolerans S3-2 (644); 15J. sp. RA13 (170); 16. J. lividum RIT308 (75); 17 J. sp. 344 (11); 18J. sp. Ant5-2-1 (136); 19J. sp. HH100 (15); 20J. sp. HH102 (72); 21 J. sp._HH103 (16); 22J. sp. HH104 (114); 23J. sp. HH106 (100); 24J. sp. HH107 (78); 25J. sp. MP5059B (136); 26J. sp. TND4EL3 (504); 27J. sp. YR213 (92)]. (PDF $85 \mathrm{~kb}$ )

Additional file 6: Table S3. List of genes encoding proteins associated with cold adaptation from strain ERGS5:01 among the 1066 core genomes of 27 strain within genus Janthinobacterium (DOCX $14 \mathrm{~kb}$ )

Additional file 7: Table S4. List of genes among the core genomes of 27 Janthinobacterium strains associated with general COG functional categories (DOCX $14 \mathrm{~kb}$ )

\section{Abbreviations}

ABM: Antarctic Bacterial Medium; ANI: Average nucleotide identities; aroE: shikimate dehydrogenase; CSPs: Cold shock proteins; DDH: DNA-DNA hybridization; gmk: guanylate kinase; gyrB: DNA gyrase B subunit; IMG: Integrated Microbial Genomes; MCC: Microbial Culture Collection;
MLSA: Multilocus sequence analysis; MR-VP: Methyl Red and Voges-Proskauer; PacBio: Pacific Biosciences; RecA: Recombinase A; rpoB: DNA-directed RNA polymerase $\beta$ subunit; tpi: triosephosphate isomerase

\section{Acknowledgements}

Authors are thankful to Sikkim State Council of Science and Technology and Department of Forest, Govt. of Sikkim for their support in sample collection. Authors duly acknowledge the technical support provided by Mohit Kumar Swarnkar for whole-genome sequencing, Anil Chaudhary for 16S rRNA gene sequencing and Robin Joshi for Scanning Electron Microscopy. This manuscript represents CSIR-IHBT communication no. 4122.

\section{Funding}

Authors are thankful to DST, Govt. of India for financial assistance under the DST INSPIRE Faculty Scheme [DST/INSPIRE/04/2014/001280] to RK. Authors also acknowledge the financial support from CSIR Network projects CeHAB (BSC0209) \& Computational Network and System Biology (MLP0076); and DBT, Gol project Bioinformatics Infrastructure Facility (BIF).

\section{Authors' contributions}

RK collected the sample, isolated bacteria, performed biochemical \& physiological characterisation and submitted WGS. RK, VA, and DS conceived the study, carried out the genome assembly, comparative analysis and provided final inputs for data analysis and discussion. RK, VA, DS, and SK drafted the manuscript and participated in overall coordination. All authors have read and approved the manuscript.

\section{Competing interests}

The authors declare that they have no competing interests.

\section{Publisher's Note}

Springer Nature remains neutral with regard to jurisdictional claims in published maps and institutional affiliations.

Received: 7 March 2017 Accepted: 4 April 2018

Published online: 19 April 2018

\section{References}

1. Gillis M, De Ley J. The genera Chromobacterium and Janthinobacterium. The prokaryotes. New York: Spring; 2006. p. 737-746.

2. Kim SJ, Shin SC, Hong SG, Lee YM, Lee H, Lee J, et al. Genome sequence of Janthinobacterium sp. strain PAMC 25724, isolated from alpine glacier cryoconite. J Bacteriol. 2012, 194:2096.

3. Glaeser SP, Kämpfer P. Multilocus sequence analysis (MLSA) in prokaryotic taxonomy. Syst Appl Microbiol. 2015;38:237-45.

4. Thompson CC, Chimetto L, Edwards RA, Swings J, Stackebrandt E, Thompson FL. Microbial genomic taxonomy. BMC Genomics. 2013;14:913.

5. Alonso-Sáez L, Zeder M, Harding T, Pernthaler J, Lovejoy C, Bertilsson S, et al. Winter bloom of a rare betaproteobacterium in the Arctic Ocean. Front Microbiol. 2014;5:425.

6. Haack FS, Poehlein A, Kröger C, Voigt CA, Piepenbring M, Bode HB, Daniel R, Schäfer W, Streit WR. Molecular Keys to the Janthinobacterium and Duganella spp. Interaction with the Plant Pathogen Fusarium graminearum. Front. Microbiol. 2016;7:1668. https://doi.org/10.3389/fmicb.2016.01668.

7. Qin Q, Xie B, Yu Y, Shu Y, Rong J, Zhang Y, et al. Comparative genomics of the marine bacterial genus Glaciecola reveals the high degree of genomic diversity and genomic characteristic for cold adaptation. Environ Microbiol. 2014;16:1642-53.

8. Kumar R, Singh D, Swarnkar MK, Singh AK, Kumar S. Complete genome sequence of Arthrobacter sp. ERGS1:01, a putative novel bacterium with prospective cold active industrial enzymes, isolated from east Rathong glacier in India. J Biotechnol. 2015;214:139-40.

9. Kumar R, Singh D, Swarnkar MK, Singh AK, Kumar S. Complete genome sequence of Arthrobacter alpinus ERGS4:06, a yellow pigmented bacterium tolerant to cold and radiations isolated from Sikkim Himalaya. J Biotechnol. 2016;220:86-7.

10. Flores MR, Ordoñez OF, Maldonado MJ, Farías ME. Full paper isolation of UV-B resistant bacteria from two high altitude Andean lakes ( 4, $400 \mathrm{~m}$ ) with saline and non saline conditions. J Gen Appl Microbiol. 2009;55:447-58. 
11. Aliyu H, De Maayer P, Cowan D. The genome of the Antarctic polyextremophile Nesterenkonia sp. AN1 reveals adaptive strategies for survival under multiple stress conditions. FEMS Microbiol Ecol. 2016;92:fiw032.

12. Goordial J, Raymond-Bouchard I, Zolotarov Y, de Bethencourt L, Ronholm J, Shapiro N, et al. Cold adaptive traits revealed by comparative genomic analysis of the eurypsychrophile Rhodococcus sp. JG3 isolated from high elevation McMurdo Dry Valley permafrost, Antarctica. FEMS Microbiol Ecol. 2016;92:fiv154.

13. Bakermans C, Bergholz PW, Rodrigues DF, Vishnivetskaya TA, Ayala-del-Río HL, Tiedje JM. Genomic and Expression Analyses of Cold-Adapted Microorganisms. In: Miller R, Whyte L, editors. Polar Microbiology: Life in a Deep Freeze. Washington, DC: ASM Press; 2012. p 126-55. https://doi.org/ 10.1128/9781555817183.ch6.

14. Agrawal A, Tayal S. Assessment of volume change in east Rathong glacier, eastern Himalaya. Int J Geoinformatics. 2013;9:73-82.

15. Shivaji S, Begum Z, Rao SSSN, Reddy PW, Manasa P, Sailaja B, et al. Antarctic ice core samples: culturable bacterial diversity. Res Microbiol. 2013;164:70-82.

16. Scott FS. Type material in the NCBI taxonomy database. Nucleic Acids Res. 2015;43(D1):D1086-98.

17. Kumar S, Stecher G, Tamura K. MEGA7: molecular evolutionary genetics analysis version 7.0 for bigger datasets. Mol Biol Evol. 2016;33(7):1870-4.

18. Field D, Garrity G, Gray T, Morrison N, Selengut J, Sterk P, et al. The minimum information about a genome sequence (MIGS) specification. Nat Biotechnol. 2008;26:541-7.

19. Kumar R, Singh D, Swarnkar MK, Singh AK, Kumar S. Genome assembly of Chryseobacterium polytrichastri ERMR1: 04, a psychrotolerant bacterium with cold active proteases, isolated from east Rathong glacier in India. Genome Announc. 2015;3:e01305-15.

20. Himanshu SMK, Singh D, Kumar R. First complete genome sequence of a species in the genus Microterricola, an extremophilic cold active enzyme producing bacterial strain ERGS5:02 isolated from Sikkim Himalaya. J Biotechnol. 2016;222:17-8.

21. Huntemann M, Ivanova NN, Mavromatis K, Tripp HJ, Paez-Espino D, Palaniappan $\mathrm{K}$, et al. The standard operating procedure of the DOEJGI microbial genome annotation pipeline (MGAP v. 4). Stand Genomic Sci. 2015;10:1.

22. Markowitz VM, Chen IM, Palaniappan K, Chu K, Szeto E, Pillay M, Ratner A, Huang J, Woyke T, Huntemann M, Anderson I. IMG 4 version of the integrated microbial genomes comparative analysis system. Nucleic Acids Res. 2013;42(D1):D560-7.

23. Markowitz VM, Mavromatis K, Ivanova NN, Chen I-MA, Chu K, Kyrpides NC. IMG ER: a system for microbial genome annotation expert review and curation. Bioinformatics. 2009;25:2271-8.

24. Mulder NJ, Apweiler R, Attwood TK, Bairoch A, Bateman A, Binns D, et al. New developments in the InterPro database. Nucleic Acids Res. 2007:35:D224-8.

25. Marchler-Bauer A, Derbyshire MK, Gonzales NR, Lu S, Chitsaz F, Geer LY, Geer RC, He J, Gwadz M, Hurwitz DI, Lanczycki CJ. CDD: NCBI's conserved domain database. Nucleic Acids Res. 2014;43(D1):D222-6.

26. Alva V, Nam SZ, Söding J, Lupas AN. The MPI bioinformatics Toolkit as an integrative platform for advanced protein sequence and structure analysis. Nucleic Acids Res. 2016;44(W1):W410-5.

27. Petersen TN, Brunak S, von Heijne G, Nielsen H. SignalP 4.0: discriminating signal peptides from transmembrane regions. Nat Methods. 2011;8:785-6.

28. Krogh A, Larsson B, Von Heijne G, Sonnhammer ELL. Predicting transmembrane protein topology with a hidden Markov model: application to complete genomes. J Mol Biol. 2001;305:567-80.

29. Grissa I, Vergnaud G, Pourcel C. CRISPRFinder: a web tool to identify clustered regularly interspaced short palindromic repeats. Nucleic Acids Res. 2007;35:W52-7.

30. Cheong WH, Tan YC, Yap SJ, Ng KP. ClicO FS: an interactive web-based service of Circos. Bioinformatics. 2015;31(22):3685-7.

31. Meier-Kolthoff JP, Göker M, Spröer C, Klenk H-P. When should a DDH experiment be mandatory in microbial taxonomy? Arch Microbiol. 2013;195:413-8.

32. Rong $X$, Huang $Y$. Multi-locus sequence analysis: taking prokaryotic systematics to the next level. Method Microbiol. 2014;41:221-51.

33. Meier-Kolthoff JP, Auch AF, Klenk H-P, Göker M. Genome sequence-based species delimitation with confidence intervals and improved distance functions. BMC Bioinformatics. 2013;14:60.

34. Richter M, Rosselló-Móra R. Shifting the genomic gold standard for the prokaryotic species definition. Proc Natl Acad SciUSA. 2009;106:19126-31.
35. Gong X, Skrivergaard S, Korsgaard BS, Schreiber L, Marshall IPG, Finster K, et al. High quality draft genome sequence of Janthinobacterium psychrotolerans sp. nov., isolated from a frozen freshwater pond. Stand Genomic Sci. 2017;12:8.

36. Graupner K, Lackner G, Hertweck C. Genome sequence of mushroom soft-rot pathogen Janthinobacterium agaricidamnosum. Genome Announc. 2015;3:e00277-15

37. Audic S, Robert C, Campagna B, Parinello H, Claverie J-M, Raoult D, et al. Genome analysis of Minibacterium massiliensis highlights the convergent evolution of water-living bacteria. PLoS Genet. 2007;3:e138.

38. Mojib N, Philpott R, Huang JP, Niederweis M, Bej AK. Antimycobacterial activity in vitro of pigments isolated from Antarctic bacteria. A Van Leeuw. 2010:98:531-40.

39. Smith H, Akiyama T, Foreman C, Franklin M, Woyke T, Teshima H, et al. Draft genome sequence and description of Janthinobacterium sp. strain CG3, a psychrotolerant Antarctic supraglacial stream bacterium. Genome Announc. 2013;1:e00960-13.

40. Hornung C, Poehlein A, Haack FS, Schmidt M, Dierking K, Pohlen A, et al. The Janthinobacterium sp. HH01 genome encodes a homologue of the V. cholerae CqsA and L. pneumophila LqsA autoinducer synthases. PLoS One. 2013;8:e55045.

41. Gan HY, Gan HM, Savka MA, Triassi AJ, Wheatley MS, Smart LB, et al. Wholegenome sequences of 13 endophytic bacteria isolated from shrub willow (Salix) grown in Geneva, New York. Genome Announc. 2014;2:e00288-14.

42. Valdes N, Soto P, Cottet L, Alarcon P, Gonzalez A, Castillo A, et al. Draft genome sequence of Janthinobacterium lividum strain MTR reveals its mechanism of capnophilic behavior. Stand Genomic Sci. 2015;10:1.

43. McTaggart TL, Shapiro N, Woyke T, Chistoserdova L. Draft genome of Janthinobacterium sp. RA13 isolated from Lake Washington sediment. Genome Announc. 2015:3:e01588-14.

44. Shoemaker WR, Muscarella ME, Lennon JT. Genome sequence of the soil bacterium Janthinobacterium sp. KBS0711. Genome Announc. 2015:3:e00689-15.

45. Smith HJ, Foreman CM, Akiyama T, Franklin MJ, Devitt NP, Ramaraj T. Genome sequence of Janthinobacterium sp. CG23 2, a Violacein-producing isolate from an Antarctic supraglacial stream. Genome Announc. 2016;4:e01468-15.

46. Chaudhari NM, Gupta VK, Dutta C. BPGA-an ultra-fast pan-genome analysis pipeline. Sci Rep. 2016;6:24373. https://doi.org/10.1038/srep24373.

47. Tettelin H, Masignani V, Cieslewicz MJ, Donati C, Medini D, Ward NL, et al. Genome analysis of multiple pathogenic isolates of Streptococcus agalactiae: implications for the microbial "pan-genome.". Pro Nat Aca SCUSA. 2005;102:13950-5.

48. Mocali S, Chiellini C, Fabiani A, Decuzzi S, de Pascale D, Parrilli E, Tutino ML, Perrin E, Bosi E, Fondi M, Giudice AL. Ecology of cold environments: new insights of bacterial metabolic adaptation through an integrated genomicphenomic approach. Sci Rep. 2017:7:839.

49. Lindström M, Dahlsten E, Söderholm H, Selby K, Somervuo P, Heap JT, Minton NP, Korkeala H. Involvement of two-component system CBO0366/ CBO0365 in the cold shock response and growth of group I (proteolytic) Clostridium botulinum ATCC 3502 at low temperatures. Appl Environ Microbiol. 2012;78(15):5466-70.

50. Lauro FM, Tran K, Vezzi A, Vitulo N, Valle G, Bartlett DH. Large-scale transposon mutagenesis of Photobacterium profundum SS9 reveals new genetic loci important for growth at low temperature and high pressure. J Bacteriol. 2008;190:1699-709.

51. Pöntinen A, Markkula A, Lindström M, Korkeala H. Two-component-system histidine kinases involved in growth of Listeria monocytogenes EGD-e at low temperatures. Appl Environ Microbiol. 2015;81:3994-4004.

52. Dsouza M, Taylor MW, Turner SJ, Aislabie J. Genomic and phenotypic insights into the ecology of from Antarctic soils. BMC Genomics. 2015;16:1

53. Chattopadhyay MK, Raghu G, Sharma Y, Biju AR, Rajasekharan MV, Shivaji S. Increase in oxidative stress at low temperature in an Antarctic bacterium. Curr Microbiol. 2011;62:544-6.

54. Liu S, Graham JE, Bigelow L, Morse PD, Wilkinson BJ. Identification of Listeria monocytogenes genes expressed in response to growth at low temperature. Appl Environ Microbiol. 2002;68:1697-705.

55. Graumann PL, Marahiel MA. A superfamily of proteins that contain the coldshock domain. Trends Biochem Sci. 1998;23:286-90.

56. Jones PG, Inouye M. The coldshock response-a hot topic. Mol Microbiol. 1994;11:811-8.

57. Yamanaka K, Fang L, Inouye M. The CspA family in Escherichia coli: multiple gene duplication for stress adaptation. Mol Microbiol. 1998;27:247-55. 
58. Hossain MM, Nakamoto H. HtpG plays a role in cold acclimation in cyanobacteria. Curr Microbiol. 2002;44:291-6.

59. Ochman H, Lawrence JG, Groisman EA. Lateral gene transfer and the nature of bacterial innovation. Nature. 2000;405:299-304.

60. Nongkhlaw M, Kumar R, Acharya C, Joshi SR. Occurrence of Horizontal Gene Transfer of PIB-type ATPase Genes among Bacteria Isolated from the Uranium Rich Deposit of Domiasiat in North East India. PLoS ONE. 2012; 7(10):e48199. https://doi.org/10.1371/journal.pone.0048199.

61. Muto A, Osawa S. The guanine and cytosine content of genomic DNA and bacterial evolution. Proc Natl Acad Sci U S A. 1987;84:166-9.

62. Macheboeuf P, Contreras-Martel C, Job V, Dideberg O, Dessen A. Penicillin binding proteins: key players in bacterial cell cycle and drug resistance processes. FEMS Microbiol Rev. 2006;30:673-91.

63. Zeng Z, Liu X, Yao J, Guo Y, Li B, Li Y, et al. Cold adaptation regulated by cryptic prophage excision in Shewanella oneidensis. ISME J. 2016;10:2787-800

64. Rai AK, Kumar R. Potential of microbial bio-resources of Sikkim Himalayan region. ENVIS Bulletin. 2015;23:99-105.

65. Woese CR, Kandler O, Wheelis ML. Towards a natural system of organisms: proposal for the domains archaea, Bacteria, and Eucarya. Proc Natl Acad Sci U S A. 1990;87:4576-9.

66. Garrity GM, Bell JA, Lilburn TE. Phylum XIV. Proteobacteria phyl. In: Garrity GM, Brenner DJ, Krieg NR, Staley JT, editors. Bergey's manual of systematic bacteriology, vol. 1. 2nd ed. New York: Springer; 2005. p. 1.

67. Garrity GM, LT BJA. Class II. Betaproteobacteria. In: Garrity GM, Brenner DJ, Krieg NR, Staley JT, editors. Bergey's manual of systematic bacteriology, vol. 1. 2nd ed. New York: Springer; 2005. p. 575.

68. Garrity GM, LT BJA. Order 1. Burkholderiales. In: Garrity GM, Brenner DJ, Krieg NR, Staley JT, editors. Bergey's manual of systematic bacteriology, vol. 1. 2nd ed. New York: Springer; 2005. p. 575.

69. Garrity GM, Bell JA, Lilburn TE. Family II. Oxalobacteraceae fam. In: Garrity GM, Brenner DJ, Krieg NR, Staley JT, editors. Bergey's manual of systematic bacteriology, vol. 1. 2nd ed. New York: Springer; 2005. p. 623.

70. Ashburner M, Ball CA, Blake JA, Botstein D, Butler H, Cherry JM, et al. Gene ontology: tool for the unification of biology. Nat Genet. 2000;25:25-9.

\section{Ready to submit your research? Choose BMC and benefit from:}

- fast, convenient online submission

- thorough peer review by experienced researchers in your field

- rapid publication on acceptance

- support for research data, including large and complex data types

- gold Open Access which fosters wider collaboration and increased citations

- maximum visibility for your research: over $100 \mathrm{M}$ website views per year 